\title{
Brazilian guidelines for the management of brain-dead potential organ donors. The task force of the AMIB, ABTO, BRICNet, and the General Coordination of the National Transplant System
}

Glauco Adrieno Westphal ${ }^{1,2,3^{*}}$, Caroline Cabral Robinson ${ }^{1}$, Alexandre Biasi Cavalcanti ${ }^{4}$, Anderson Ricardo Roman Gonçalves ${ }^{5,6}$, Cátia Moreira Guterres ${ }^{1}$, Cassiano Teixeira ${ }^{7,8}$, Cinara Stein ${ }^{1}$, Cristiano Augusto Franke ${ }^{7,9}$, Daiana Barbosa da Silva', Daniela Ferreira Salomão Pontes ${ }^{10}$, Diego Silva Leite Nunes ${ }^{10}$, Edson Abdala ${ }^{11}$, Felipe Dal-Pizzol ${ }^{12,13}$, Fernando Augusto Bozza ${ }^{14,15}$, Flávia Ribeiro Machado ${ }^{16}$, Joel de Andrade ${ }^{17}$, Luciane Nascimento Cruz ${ }^{1}$ Luciano Cesar Pontes de Azevedo ${ }^{18}$, Miriam Cristine Vahl Machado ${ }^{3}$, Regis Goulart Rosa ${ }^{1}$, Roberto Ceratti Manfro, ${ }^{79}$, Rosana Reis Nothen ${ }^{19}$, Suzana Margareth Lobo ${ }^{20}$, Tatiana Helena Rech7, Thiago Lisboa ${ }^{7}$, Verônica Colpani ${ }^{1}$ and Maicon Falavigna ${ }^{1,21,22}$

\begin{abstract}
Objective: To contribute to updating the recommendations for brain-dead potential organ donor management. Method: A group of 27 experts, including intensivists, transplant coordinators, transplant surgeons, and epidemiologists, joined a task force formed by the General Coordination Office of the National Transplant System/Brazilian Ministry of Health (CGSNT-MS), the Brazilian Association of Intensive Care Medicine (AMIB), the Brazilian Association of Organ Transplantation (ABTO), and the Brazilian Research in Intensive Care Network (BRICNet). The questions were developed within the scope of the 2011 Brazilian Guidelines for Management of Adult Potential Multiple-Organ Deceased Donors. The topics were divided into mechanical ventilation, hemodynamic support, endocrine-metabolic management, infection, body temperature, blood transfusion, and use of checklists. The outcomes considered for decision-making were cardiac arrest, number of organs recovered or transplanted per donor, and graft function/survival. Rapid systematic reviews were conducted, and the quality of evidence of the recommendations was assessed using the Grading of Recommendations Assessment, Development, and Evaluation (GRADE) system. Two expert panels were held in November 2016 and February 2017 to classify the recommendations. A systematic review update was performed in June 2020, and the recommendations were reviewed through a Delphi process with the panelists between June and July 2020.
\end{abstract}

Results: A total of 19 recommendations were drawn from the expert panel. Of these, 7 were classified as strong (lung-protective ventilation strategy, vasopressors and combining arginine vasopressin to control blood pressure,

\footnotetext{
*Correspondence: glauco.ww@gmail.com.br

${ }^{1}$ Hospital Moinhos de Vento (HMV), R. Ramiro Barcelos, 910, Porto Alegre,

RS 90035000, Brazil

Full list of author information is available at the end of the article
} in this article are included in the article's Creative Commons licence, unless indicated otherwise in a credit line to the material. If material is not included in the article's Creative Commons licence and your intended use is not permitted by statutory regulation or exceeds the permitted use, you will need to obtain permission directly from the copyright holder. To view a copy of this licence, visit http://creativeco mmons.org/licenses/by/4.0/. 
antidiuretic hormones to control polyuria, serum potassium and magnesium control, and antibiotic use), 11 as weak (alveolar recruitment maneuvers, low-dose dopamine, low-dose corticosteroids, thyroid hormones, glycemic and serum sodium control, nutritional support, body temperature control or hypothermia, red blood cell transfusion, and goal-directed protocols), and 1 was considered a good clinical practice (volemic expansion).

Conclusion: Despite the agreement among panel members on most recommendations, the grade of recommendation was mostly weak. The observed lack of robust evidence on the topic highlights the importance of the present guideline to improve the management of brain-dead potential organ donors.

Keywords: Guidelines, Organ donation, Intensive care, Brain death, GRADE

\section{Introduction}

Organ donation for transplantation is a complex process led by several health care professionals responsible for a sequence of actions and procedures that begin with identifying a potential organ donor and end with organ procurement surgery and distribution. The progress of this process is essential to increase the deceased-donor pool, and to decrease the growing disparity between the number of patients on transplant waiting lists and the availability of organs $[1,2]$.

The organ donation process includes the identification of the potential donor, diagnosis of brain death, family support and interview, evaluation of donor eligibility criteria, clinical management of the potential organ donor, and organ procurement and distribution [2,3]. Given the marked clinical instability that occurs in patients who progress to brain death, the application of potential donor-management strategies aiming at hemodynamic stabilization is crucial to avoid loss of organs due to hypoperfusion or loss of donors due to cardiac arrest. Also, the control of ventilatory support, body temperature, and endocrine-metabolic functions contributes to improving the quality of organs and clinical outcomes in transplant recipients $[1,2,4,5]$.

Despite the lack of evidence on some aspects of the clinical management of potential organ donors, the recommendations presented in this guideline intend to promote a general approach to mitigate the disparity between supply and demand of organs for transplantation.

\section{Objective}

To provide recommendations to guide the clinical management of brain-dead potential organ donors aiming to reduce the rate of cardiac arrest of the potential donor and to improve organ viability for transplantation.

\section{Method}

The present document provides a partial update on the 2011 Brazilian Guidelines for Management of Adult Potential Multiple-Organ Deceased Donors [6-8]. The working group consisted of physicians, nurses, pharmacists, physical therapists, epidemiologists, methodologists, and transplant system managers. The contributions of each participant are shown in Additional file 1, and the respective conflict-of-interest disclosures are shown in Additional file 2.

The target audience of this guideline is health care professionals, especially physicians and nursing staff working in adult ICUs and emergency departments, who are involved in the care of adult individuals with known or suspected brain death.

The clinical issues addressed by the guideline were defined by coordinators of the working group and the methodologists in a face-to-face meeting held in March 2016, after reviewing the recommendations of the 2011 Brazilian Guidelines for Management of Adult Potential Multiple-Organ Deceased Donors [6-8]. The issues were prioritized according to the perception of their impact on medical management and variability in clinical practice and divided into the following major topics: (1) ventilatory support; (2) hemodynamic support; (3) endocrine, metabolic and nutritional management; (4) specific aspects that include infection and sepsis, red blood cell transfusion, and body temperature control; and (5) goaldirected therapy. For each clinical issue, operational questions were developed and framed using the PICO (population-intervention-comparison-outcome) format. The population of interest consists of potential organ donors with known or suspected brain death [3], hereafter referred to as potential donors. The outcomes considered for decision-making were cardiac arrest, the number of organs recovered or transplanted per donor, and graft function or graft survival.

For each clinical issue, rapid systematic reviews $[9,10]$ were conducted using the following search strategy: (1) Review of the reference lists of Brazilian guidelines [6-8] and the Society of Critical Care Medicine (SCCM) [11] statement on the management of the potential organ donor; (2) Review of related topics in the DynaMed and UpToDate databases; and (3) PubMed search focusing on systematic reviews and clinical trials published until October 2016 and until January 2017. Quality of evidence was assessed using the Grading of Recommendations 
Assessment, Development, and Evaluation (GRADE) system [12].

The recommendations were prepared and submitted to two face-to-face expert panels held in November 2016, and February 2017. For each recommendation, the direction of the course of action was discussed (whether to perform or not to perform the proposed action), and the strength of the recommendation was classified as strong or weak according to the GRADE system [12]. After the last panel meeting, a new systematic search covering the period from October 2016 to May 2020 was carried out to identify new evidence that could potentially modify the recommendations. From June to July 2020, a Delphi process was performed with the panelists to present the results of the literature update and review the direction and strength of the recommendations.

\section{Results}

A total of 19 recommendations were drawn from the expert panel. Of these, 7 were classified as strong, 11 as weak, and 1 was considered as good clinical practice. Table 1 shows a summary of the recommendations. Figure 1 presents graphically the flow of the recommendations along the clinical management. Additional file 3 provides a checklist with the main recommendations with a positive direction of action to assist in bedside monitoring of clinical goals related to the recommendations and in the application of the management strategies.

\section{Ventilatory support}

1. We recommend using a lung-protective ventilation strategy in all potential donors (low level of evidence, strong recommendation).

Summary of evidence In potential donors, an initially normal or near-normal lung function $\left(\mathrm{PaO}_{2} / \mathrm{FiO}_{2} \geq 300\right)$ may deteriorate due to common complications in critical patients, such as pulmonary contusion, lung injury following blood transfusion, pneumonia, atelectasis, and mechanical ventilation-related iatrogenic injuries [13-18]. In addition, approximately $30-45 \%$ of potential donors develop acute respiratory distress syndrome (ARDS; $\mathrm{PaO}_{2} / \mathrm{FiO}_{2}<300$ ), and only $15-20 \%$ of the lungs are suitable for transplantation at the end of the procurement process $[13,15,17]$. The lung-protective ventilation strategy in potential donors with normal lungs and the apnea testing performed with continuous positive airway pressure (CPAP) have been associated with an increase in eligibility for lung donation [18-20].

Remarks The protective ventilation strategy for healthy lungs consists of the combination of a tidal volume of $6-8 \mathrm{~mL} / \mathrm{kg}$ and PEEP of $8-10-\mathrm{cm}_{2} \mathrm{O}$. To promote adequate blood oxygenation, $\mathrm{FiO}_{2}$ and PEEP must be adjusted to obtain a $\mathrm{SaO}_{2}>90 \%$. To avoid atelectasis, the apnea test with $10 \mathrm{~cm} \mathrm{H}_{2} \mathrm{O}$ CPAP can be performed using a closed-circuit system in potential donors with preserved lungs who are candidates for lung procurement, or even when hypoxemic respiratory failure is present. Also, the same procedure can be considered on those who have failed the test due to hypoxemia after disconnection.

2. We suggest not using alveolar recruitment maneuvers routinely in potential donors (very low level of evidence, weak recommendation).

Summary of evidence Although alveolar recruitment maneuvers have been suggested for the ventilatory management of organ donors with lung injury $\left(\mathrm{PaO}_{2} /\right.$ $\left.\mathrm{FiO}_{2}<300\right)[13-16,18,20]$, and these maneuvers could reduce hypoxemia after apnea testing, contributing to increasing the viability of pulmonary grafts $[14-18,20]$, a randomized clinical trial showed unfavorable outcomes in critically ill patients [21]. Besides, no randomized studies have demonstrated their efficacy in the population of potential donors.

Remarks Performing alveolar recruitment maneuvers in hemodynamically stable potential donors is probably feasible in units with experience in the management of ARDS. In cases of hypoxemia refractory to the lung-protective ventilation strategy, however, alveolar recruitment maneuvers should not be performed routinely. Their use is not indicated in hemodynamically unstable potential donors.

\section{Hemodynamic support \\ Volemic expansion and vasopressors}

3. We recommend performing initial volemic expansion in hemodynamically unstable potential donors with hypovolemia or responsive to fluids according to fluid responsiveness assessment (good clinical practice).

4. We recommend administering norepinephrine or dopamine to control blood pressure in potential donors who remain hypotensive after volemic expansion (very low level of evidence, strong recommendation).

Summary of evidence Potential donor hypotension is associated with a higher incidence of postoperative liver graft dysfunction and longer hospital stay in liver transplant recipients $[22,23]$. Targeting a mean arterial pressure $(\mathrm{MAP}) \geq 65 \mathrm{~mm} \mathrm{Hg}$ has also been associated with reduced occurrence of cardiac arrest in potential donors 


\section{Table 1 Summary of recommendations}

\begin{tabular}{|c|c|c|c|}
\hline Recommendations & Level of evidence & Grade of recommendation & Practical considerations \\
\hline \multicolumn{4}{|l|}{ Ventilatory support } \\
\hline $\begin{array}{l}\text { 1. We recommend using a lung-protective venti- } \\
\text { lation strategy in all PDs }\end{array}$ & Low & Strong & $\begin{array}{l}\text { Vt between } 6 \text { and } 8 \mathrm{~mL} / \mathrm{kg} \text { of predicted body weight } \\
\text { and PEEP of } 8-10-\mathrm{cm} \mathrm{H}_{2} \mathrm{O} \\
\text { Adjust } \mathrm{FiO}_{2} \text { and PEEP to obtain } \mathrm{SaO}_{2}>90 \% \\
\text { Perform apnea testing with CPAP }\end{array}$ \\
\hline 2. We suggest not using ARM routinely in PDs & Very low & Weak & $\begin{array}{l}\text { ARM can be considered if there is refractory hypox- } \\
\text { emia in hemodynamically stable PDs }\end{array}$ \\
\hline \multicolumn{4}{|l|}{ Hemodynamic support } \\
\hline $\begin{array}{l}\text { 3. We recommend performing initial volemic } \\
\text { expansion in hemodynamically unstable PDs } \\
\text { with hypovolemia or responsive to fluids } \\
\text { according to fluid responsiveness assessment }\end{array}$ & & Good clinical practice & $\begin{array}{l}\text { Initial volume expansion with } 30 \mathrm{~mL} / \mathrm{kg} \text { of crystal- } \\
\text { loids } \\
\text { Assess fluid status and responsiveness for additional } \\
\text { fluid replacement } \\
\text { Preferably use dynamic parameters } \\
\text { Neutral or negative fluid balance after achieving } \\
\text { hemodynamic stability }\end{array}$ \\
\hline $\begin{array}{l}\text { 4. We recommend administering norepineph- } \\
\text { rine or dopamine to control blood pressure } \\
\text { in PDs who remain hypotensive after volemic } \\
\text { expansion }\end{array}$ & Very low & Strong & $\begin{array}{l}\text { Start adrenergic vasopressors to obtain a } \\
\text { MAP } \geq 65 \mathrm{~mm} \mathrm{Hg} \\
\text { Dopamine is the vasopressor of choice when there } \\
\text { is bradycardia } \\
\text { Consider the potential arrhythmogenic effect of } \\
\text { dopamine, which implies the risk of PD loss due to } \\
\text { cardiac arrest }\end{array}$ \\
\hline $\begin{array}{l}\text { 5. We suggest not using low-dose dopamine for } \\
\text { renal protection in PDs }\end{array}$ & Very low & Weak & $\begin{array}{l}\text { Consider the potential arrhythmogenic effect of } \\
\text { dopamine, which implies the risk of PD loss due to } \\
\text { cardiac arrest }\end{array}$ \\
\hline \multicolumn{4}{|l|}{ Endocrine and electrolyte management } \\
\hline $\begin{array}{l}\text { 6. We recommend combining AVP in PDs receiv- } \\
\text { ing norepinephrine or dopamine }\end{array}$ & Low & Strong & $\begin{array}{l}\text { Combine AVP (1 IU bolus + 0.5-2.4 IU/h) with norepi- } \\
\text { nephrine or dopamine }\end{array}$ \\
\hline $\begin{array}{l}\text { 7. We recommend administering AVP or DDAVP } \\
\text { to control polyuria in PDs with diabetes } \\
\text { insipidus }\end{array}$ & Low & Strong & $\begin{array}{l}\text { AVP if vasopressors are required. } \\
\text { DDAVP }(1-2-\mu g \text { IV } 2-4 \text { h) if vasopressors are not } \\
\text { required }\end{array}$ \\
\hline $\begin{array}{l}\text { 8. We suggest combining low-dose corticos- } \\
\text { teroids in PDs receiving norepinephrine or } \\
\text { dopamine }\end{array}$ & Low & Weak & $\begin{array}{l}\text { Combine } 300 \text { mg IV/day in PDs with norepinephrine } \\
\text { or dopamine }\end{array}$ \\
\hline $\begin{array}{l}\text { 9. We suggest not using thyroid hormones } \\
\text { routinely in PDs }\end{array}$ & Very low & Weak & $\begin{array}{l}\text { There are no hemodynamic benefits } \\
\text { They can be considered if prolonged management } \\
\text { is required }\end{array}$ \\
\hline $\begin{array}{l}\text { 10. We suggest performing glycemic control in } \\
\text { PDs }\end{array}$ & Very low & Weak & $\begin{array}{l}\text { Administer insulin to achieve a glucose level of } \\
\quad 140-180 \mathrm{mg} / \mathrm{dL} \\
\text { Monitor blood glucose at least every } 6 \mathrm{~h}\end{array}$ \\
\hline $\begin{array}{l}\text { 11. We suggest maintaining serum sodium } \\
\text { levels }<155 \mathrm{mEq} / \mathrm{dL} \text { in PDs }\end{array}$ & Very low & Weak & $\begin{array}{l}\text { Correct water deficit with hypotonic fluids } \\
\text { Correct hypovolemia }\end{array}$ \\
\hline $\begin{array}{l}\text { 12. We recommend maintaining serum potas- } \\
\text { sium levels between } 3.5 \text { and } 5.5 \mathrm{mEq} / \mathrm{L} \text { in PDs }\end{array}$ & Very low & Strong & \\
\hline $\begin{array}{l}\text { 13. We recommend maintaining serum magne- } \\
\text { sium levels }>1.6 \mathrm{mEq} / \mathrm{L} \text { in PDs }\end{array}$ & Very low & Strong & \\
\hline \multicolumn{4}{|l|}{ Other aspects } \\
\hline $\begin{array}{l}\text { 14. We suggest maintaining nutritional support in } \\
\text { PDs if well tolerated }\end{array}$ & Very low & Weak & \\
\hline $\begin{array}{l}\text { 15. We recommend using antibiotics in PDs with } \\
\text { infection or sepsis }\end{array}$ & Low & Strong & $\begin{array}{l}\text { Maintain appropriate antibiotic therapy in the donor } \\
\text { for at least } 24 \mathrm{~h} \\
\text { Collect cultures from different sites in all donors }\end{array}$ \\
\hline $\begin{array}{l}\text { 16. We suggest maintaining body temperature } \\
\text { above } 35^{\circ} \mathrm{C} \text { in hemodynamically unstable PDs }\end{array}$ & Very low & Weak & $\begin{array}{l}\text { Monitor core temperature } \\
\text { Prevent and treat hypothermia in PDs receiving } \\
\text { vasoactive amines }\end{array}$ \\
\hline $\begin{array}{l}\text { 17. We suggest inducing hypothermia }\left(34-35^{\circ} \mathrm{C}\right) \\
\text { in PDs without hemodynamic instability }\end{array}$ & Low & Weak & $\begin{array}{l}\text { Monitor core temperature } \\
\text { Induce hypothermia by applying ice packs in PDs not } \\
\text { receiving vasoactive amines }\end{array}$ \\
\hline $\begin{array}{l}\text { 18. We suggest transfusing packed red blood cells } \\
\text { in PDs with hemoglobin levels }<7 \mathrm{~g} / \mathrm{dL}\end{array}$ & Very low & Weak & \\
\hline $\begin{array}{l}\text { 19. We suggest using goal-directed protocols dur- } \\
\text { ing the management of PDs }\end{array}$ & Very low & Weak & $\begin{array}{l}\text { Monitor care using evidence-based clinical goal- } \\
\text { directed checklists }\end{array}$ \\
\hline
\end{tabular}


Table 1 (continued)

PD: potential donor; $\mathrm{Vt}$ : total volume; PEEP: positive-end expiratory pressure; $\mathrm{SaO}_{2}$ : arterial oxygen saturation; CPAP: continuous positive airway pressure; $\mathrm{ARM}$ : alveolar recruitment maneuver; MAP: mean arterial pressure; AVP: arginine-vasopressin; DDAVP: 1-deamino-8-D-arginine-vasopressin; IV: intravenous

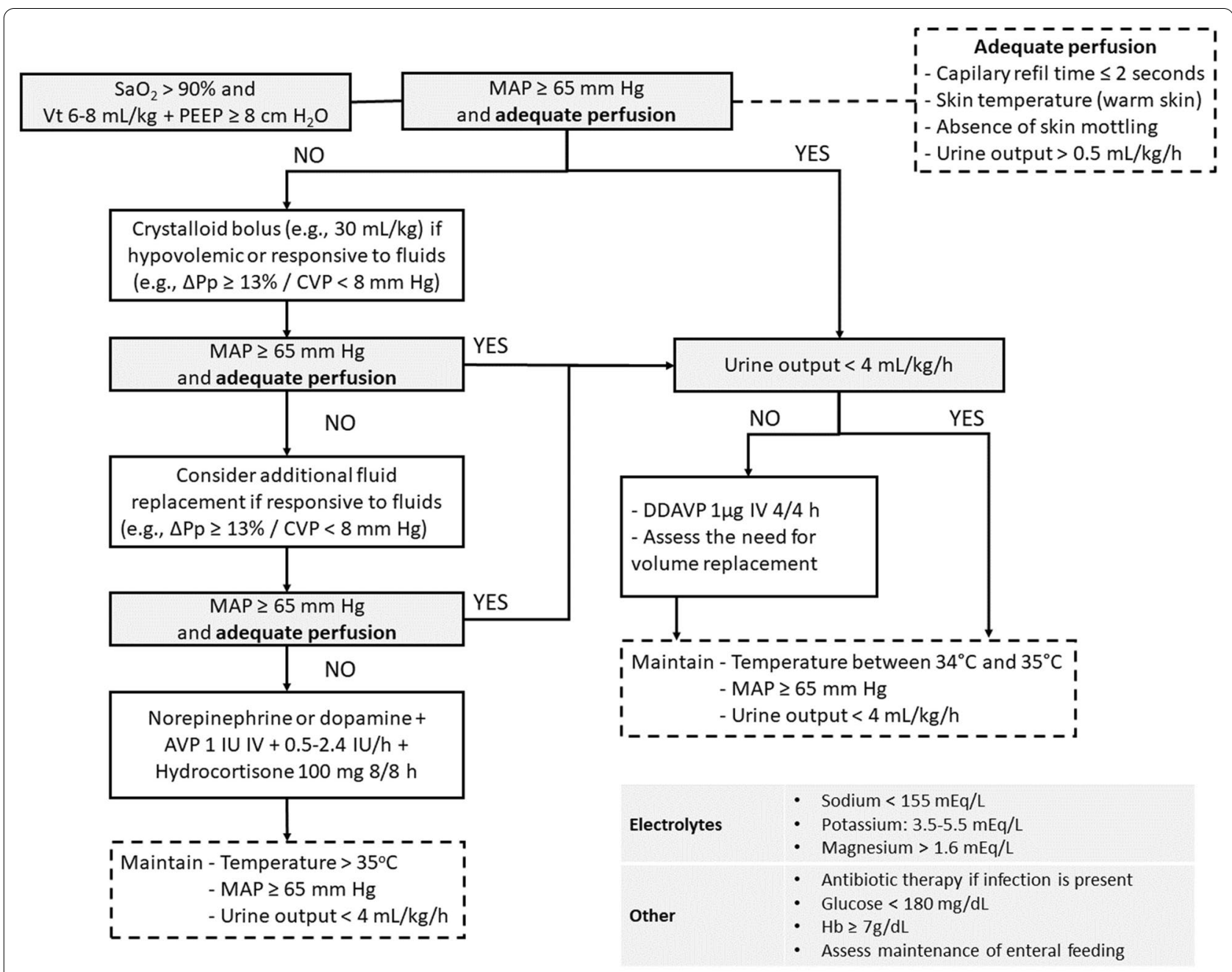

Fig. 1 Flow of the recommendations

$[22,24]$. Intravascular volume expansion guided by ventricular filling pressures or respiratory pulse pressure variation (PPV) in hemodynamically unstable potential donors is associated with faster recovery of renal graft function and reduced circulating levels of inflammatory cytokines $[22,25]$. A randomized trial detected no difference between usual fluid management or fluid management directed by a PPV and cardiac index. On the other hand, there was a trend toward an increase in the number of organs transplanted per donor among unstable potential donors responsive to fluids $(p=0.059)$ [26].

Conversely, avoiding fluid overload after the initial volume resuscitation to stabilize blood pressure seems to be beneficial. This approach is associated with a greater number of organs transplanted per donor and a greater number of lungs transplanted without reducing the number of other donated organs or impairing survival in the heart, liver, pancreas, or kidney transplant recipients [19, 27-29].

If hypotension persists after adequate volume resuscitation, adrenergic vasopressors should be used to achieve adequate blood-pressure levels [30]. There is no difference in clinical outcomes in studies comparing norepinephrine and dopamine [31-33]. Disruption of vagal activity secondary to brain death may result in atropinerefractory bradycardia. In these cases, adrenergic drugs 
as isoproterenol, epinephrine, and dopamine have been suggested as positive chronotropic agents to treat bradycardia in potential donors. Considering the predominance of noradrenaline action on alpha-1 receptors, its infusion usually occurs without significant increase in heart rate. Hence, dopamine or epinephrine may be more convenient for the treatment of hypotension due to a positive chronotropic effect [6, 34, 35].

Remarks Obtaining an MAP $\geq 65 \mathrm{~mm} \mathrm{Hg}$ as a bloodpressure target contributes to the perfusion of organs that are intended to be preserved for transplantation [22-24]. Hypovolemia is very frequent in potential organ donors and should be considered when hypotension is present. The initial infusion of crystalloids (e.g., $30 \mathrm{~mL} /$ $\mathrm{kg}$ ) in potential donors who are hypovolemic or responsive to fluids (when any fluid responsiveness assessment parameter is already available) contributes to blood-pressure control by improving tissue perfusion [24-26].

Conversely, fluid overload should be avoided [19, 27-29]. Assessment of fluid responsiveness with static variables (e.g., central venous pressure-CVP) and/or dynamic parameters (e.g., PPV) can be used to guide volume replacement, helping to prevent fluid overload. Dynamic parameters can more accurately discriminate between responsive and unresponsive individuals [3038]. Once hemodynamic stability is achieved, strategies aimed at neutral fluid balance may be more beneficial [19, 27-29].

If the blood-pressure target is not achieved with the initial volume expansion, norepinephrine or dopamine infusion should be started immediately. The use of dopamine is likely advantageous for cases of bradycardia with signs of low cardiac output $[6,34,35]$, but the arrhythmogenic potential of dopamine should be considered [39].

5. We suggest not using low-dose dopamine for renal protection in potential donors (very low level of evidence, weak recommendation).

Summary of evidence A cohort study of 93 heart transplant recipients showed that pretreatment with low-dose dopamine $(4 \mu \mathrm{g} / \mathrm{kg} / \mathrm{min})$ in heart donors was associated with higher graft survival 3 years after transplantation (87.0 vs. $67.8 \%, p<0.03$ ) [40]. A randomized-controlled trial of 264 organ donors reported that the administration of low-dose dopamine reduced the need for hemodialysis in recipients (OR 0.54; 95\% CI 0.35-0.83), but with no benefits for kidney graft survival after 3 years [41]. In the 5-year follow-up analysis of 487 renal transplant recipients from the same trial, the researchers failed to show a significant advantage of dopamine administration in potential donors to long-term kidney graft survival, although time of dopamine infusion and graft failure were exposure-related (HR 0.96; 95\% CI 0.92-1.00, per hour) [42]. The same group reported that low-dose dopamine did not negatively affect the short- or long-term outcomes after liver transplants [43].

Remarks Although the administration of low-dose dopamine in potential donors reduces the need for multiple dialysis sessions, the long-term benefits for heart and kidney graft survival are unclear. The panel considered the potential arrhythmogenic effect of dopamine, which may imply a greater risk of loss of potential donors due to cardiac arrest before organ procurement.

\section{Endocrine and electrolyte management Hormones}

6. We recommend combining arginine vasopressin (AVP) in potential donors receiving norepinephrine or dopamine to control blood pressure (low level of evidence, strong recommendation).

Summary of evidence The use of AVP in brain-dead potential donors contributes to reducing the need for adrenergic vasopressors and is associated with a lower incidence of cardiovascular deterioration and cardiac arrest [44-48], in addition to contributing to the control of plasma hyperosmolarity [46]. AVP infusion allows, in some cases, complete discontinuation of adrenergic vasopressors without causing adverse effects on the function of organs transplanted [48, 49]. Finally, AVP infusion seems to be associated with a greater number of donated organs and a lower rate of graft refusal due to organ dysfunction [45].

Remarks The administration of an initial 1 IU AVP bolus followed by infusion of $0.5 \mathrm{IU} / \mathrm{h}$ to $2.4 \mathrm{UI} / \mathrm{h}$ helps to maintain blood pressure in potential donors requiring vasopressors, and contributes to the control of polyuria and normovolemia in the presence of diabetes insipidus [44-46, 48, 49]. AVP should be started at the same time of adrenergic vasopressor infusion.

7. We recommend administering AVP or 1-deamino-8-D-arginine vasopressin (DDAVP) to control polyuria in potential donors with diabetes insipidus (low level of evidence, strong recommendation).

Summary of evidence The analysis of the database of a randomized clinical trial that evaluated 487 renal graft recipients showed better control of daily urine output $(p<0.001)$ and a lower need for fluids in the DDAVP group $(p<0.001)$. DDAVP was associated with improved renal graft survival (85.4\% vs. $73.6 \%, p=0.003)$ after 2 years, with no differences in acute rejections (OR 1.32; 
95\% CI 0.70-2.49) or delayed graft function (OR 0.97; 95\% CI 0.57-1.65) [50].

Remarks DDAVP acts exclusively on V2 receptors and is indicated to control polyuria (urine output $>4 \mathrm{~mL} /$ $\mathrm{kg} / \mathrm{h}$ ) in potential donors with diabetes insipidus who maintain adequate blood pressure without adrenergic vasopressors. AVP is preferred to control polyuria in potential donors with diabetes insipidus who need adrenergic vasopressors. The combination of AVP and DDAVP may be considered in refractory cases [51]. Although the intranasal route is feasible, DDAVP should preferably be administered intravenously, at a dose of $1-2 \mu \mathrm{g}$ every $2-4 \mathrm{~h}[8,13,15]$, until a urine output $<4 \mathrm{~mL} / \mathrm{kg} / \mathrm{h}$ has been achieved [50-53].

8. We suggest using low-dose corticosteroids in potential donors receiving norepinephrine or dopamine to control blood pressure (low level of evidence, weak recommendation).

Summary of evidence A small retrospective study reported that administration of $15-\mathrm{mg} / \mathrm{kg}$ methylprednisolone was associated with higher $\mathrm{PaO}_{2} / \mathrm{FiO}_{2}$ values $(p=0.01)$ and a greater number of lungs transplanted $(p<0.01)$ [54]. Conversely, a before-and-after study comparing $15-\mathrm{mg} / \mathrm{kg}$ methylprednisolone with $300-\mathrm{mg}$ hydrocortisone found no difference in the oxygenation and hemodynamic stability of the potential donor or in the number of organs transplanted [55]. A recent small randomized-controlled trial showed that a single dose of $15 \mathrm{mg} / \mathrm{kg} /$ day of methylprednisolone administered to the potential organ donor may negatively affect the graft function by increasing the antigenicity of the kidneys before transplantation. This negative effect was not noticed among brain-dead donors who received $15 \mathrm{mg} /$ $\mathrm{kg} /$ day of methylprednisolone followed by $100 \mathrm{mg}$ every $2 \mathrm{~h}$ until organ harvesting [56]. Eleven randomizedcontrolled trials analyzed in a systematic review did not support the use of high-dose corticosteroids in the management of potential donors [57]. On the other hand, a randomized multicenter cluster study including 259 individuals compared the administration of low-dose hydrocortisone (300 mg/day) with no corticosteroids. The doses $(p=0.03)$ and duration of infusion $(p<0.001)$ of vasopressors were lower in the intervention group, and the complete vasopressor withdrawal was 4.7 times more frequent in the corticosteroid group [58].

Remarks Despite conflicting evidence, the use of corticosteroids is of low cost and a low risk to potential donors and may have a positive effect on hemodynamic outcomes; therefore, their use is indicated in these patients. Current evidence does not suggest ventilatory or hemodynamic benefits associated with corticosteroid therapy at high doses compared with low doses (i.e., $100 \mathrm{mg}$ every $8 \mathrm{~h})$. Higher doses should be avoided.

9. We suggest not using thyroid hormones routinely in potential donors (very low level of evidence, weak recommendation).

Summary of evidence Administration of thyroid hormones in potential donors did not add any benefit, such as a reduction in vasopressor use, an increase in cardiac index, or an increase in organ procurement for transplantation [59-65]. Observational studies had suggested an increase in heart procurement, which was not confirmed in randomized clinical trials $[66,67]$, even in brain-dead organ donors with hemodynamic instability and/or impaired cardiac function [68,69].

Remarks Brain death is associated with a drop in circulating thyroid hormone levels, which could contribute to hemodynamic instability; however, there is no evidence to support the use of thyroid hormones in potential donors, given their costs and risks.

10. We suggest performing glycemic control in potential donors (very low level of evidence, weak recommendation).

Summary of evidence Four observational studies evaluated the effect of potential donor hyperglycemia on post-transplant pancreatic function [70-73]. One study showed a correlation between donor blood glucose immediately before organ retrieval and HbA1C 1 year after transplantation [73], and another study found an association between hyperglycemia and graft loss (HR 1.4; $p=0.03$ ) [74]. Two studies showed no association between potential donor blood glucose and post-transplant pancreatic graft function [70-72]. One observational study found an association between glycemic control and creatinine of the potential donor before organ retrieval [75]. Conversely, there is no evidence that hyperglycemia is associated with liver graft dysfunction [76]. A study of 1611 potential donors reported that a glucose level $<180 \mathrm{mg} / \mathrm{dL}$ was an independent predictor of four or more organs transplanted per donor (OR 1.35; 95\% CI 1.01-1.82) [77]. A set of potential donor care measures, including glycemic control, was associated with achieving $\geq 3$ organs transplanted per donor (OR 1.9; $95 \%$ CI 1.35-2.68), but it was not possible to assess the isolated effect of glycemic control [78].

Remarks Very-low-quality evidence suggests that a glucose level $<180 \mathrm{mg} / \mathrm{dL}$ is associated with a greater number of organs transplanted. Blood glucose should be monitored in all potential donors at least every $6 \mathrm{~h}$, targeting levels of $140-180 \mathrm{mg} / \mathrm{dL}$, and intravenous insulin infusion can be used to this end. 


\section{Electrolytes}

11. We suggest maintaining serum sodium levels below $155 \mathrm{mEq} / \mathrm{dL}$ in potential donors (very low level of evidence, weak recommendation).

Summary of evidence. Five descriptive observational studies were identified $(n=5733)$, which evaluated only graft viability/function. In four of these studies $(n=5545)$, there was no negative effect of donor hypernatremia above $155 \mathrm{mEq} / \mathrm{L}$ on liver or heart graft function [79-82]. In only one study $(n=188)$, hypernatremia was associated with more cases of early graft loss [83]. Some authors have suggested that deceased-donor hypernatremia may be a factor for worse prognosis of graft function, but these findings have not been universally confirmed [79-85]. Changes in natremia may reflect inadequate volume management, especially in the presence of diabetes insipidus, one of the reasons for its correction [11].

Remarks Hypernatremia is often associated with hypovolemia, and should be controlled with volume expansion, replacement of hypotonic fluids, and control of polyuria with AVP or DDAVP. Serum sodium should be monitored, targeting levels $<155 \mathrm{mg} / \mathrm{dL}$.

12. We recommend maintaining serum potassium levels between 3.5 and $5.5 \mathrm{mEq} / \mathrm{L}$ in potential donors (very low level of evidence, strong recommendation).

Summary of evidence There are no studies that directly evaluate the effect of hyper- or hypokalemia in potential donors. A comparison of potassium levels in ICU patients showed that hyperkalemia was more common in patients who died $(9.2 \%$ vs. $0.9 \%, p<0.001)$ and that serum potassium concentration could be a predictor of death in critically ill patients [86].

Remarks Despite the absence of studies directly evaluating the effects of potential donor serum potassium levels, potassium is a determining factor in the resting potential of electrically sensitive cells. Changes in potassium levels are related to cardiac arrhythmias and may compromise the management of potential donors. Potassium levels should be monitored, and usual correction measures should be implemented, targeting serum levels between 3.5 and $5.5 \mathrm{mEq} / \mathrm{L}$.

13. We recommend maintaining serum magnesium levels above $1.6 \mathrm{mEq} / \mathrm{L}$ in potential donors (very low level of evidence, strong recommendation).

Summary of evidence Studies on the influence of serum magnesium levels were found in critically ill patients, but none in potential donors [87-92]. Two observational studies and one randomized study identified an association between hypomagnesemia and higher mortality in critically ill patients $[87,88,91]$, in addition to a greater likelihood of QT interval prolongation (OR 42.8; 95\% CI 14.5-126.2) [88]. This association of hypomagnesemia with mortality was reinforced in a systematic review [89]. In addition to being arrhythmogenic, hypomagnesemia appears to be associated with nonrecovery of renal function in patients with acute kidney injury (70\% vs. $31 \%, p=0.003)$ [92].

Remarks Hypomagnesemia is associated with cardiac arrhythmias and worse prognosis in critically ill patients, with no direct evidence in brain-dead potential donors. However, this is a low-cost procedure, and in the ICU setting, routine monitoring until normalization of magnesium levels is a common practice, which may be beneficial for potential donors. Magnesium levels should be monitored, and magnesium sulfate should be administered, as usual, targeting serum levels above $1.6 \mathrm{mEq} / \mathrm{L}$.

\section{Other aspects of potential donor management Nutritional support}

14. We suggest maintaining nutritional support in potential donors if well tolerated (very low level of evidence, weak recommendation).

Summary of evidence Although there is no evidence on nutritional support, different guidelines recommend continuing nutritional support of the donor in the absence of contraindications $[7,9,51]$. Possible benefits include increased liver glycogen reserves, which could positively influence the liver graft $[93,94]$, and maintenance of intestinal mucosal trophism, which could reduce the potential for bacterial translocation.

Remarks For brain-dead individuals requiring ICU management for prolonged periods (e.g., brain-dead pregnant women; prolongation of the diagnostic process or the family decision for donation), it is reasonable that energy expenditure should be estimated or measured [95], considering that baseline energy expenditure is $15-30 \%$ lower in brain-dead individuals than in other critically ill patients [96]. Thus, in individuals already receiving full nutritional support, energy intake may be reduced once brain death is established. A minimum energy intake (e.g., $500 \mathrm{kcal}$ ) could be considered in potential donors who had not been on enteral feeding before brain death was diagnosed, taking into account its potential benefit in the maintenance of intestinal mucosal trophism. However, it does not seem appropriate to start enteral feeding when the organs are likely to be harvested within a short period or in the presence of any of the usual contraindications to initiate/maintain enteral feeding (e.g., gastrointestinal tract obstruction, ileus, 
vomiting/aspiration of gastric contents, severe hemodynamic instability, and high doses of vasopressors).

\section{Infection and sepsis}

15. We recommend using antibiotics in potential donors with infection or sepsis (low level of evidence, strong recommendation).

Summary of evidence Different observational studies evaluated the transmission of bacterial infection in organ donors with culture-proven infection. The most commonly observed microorganisms were Staphylococcus aureus, Streptococcus sp., Klebsiella sp., and Acinetobacter baumannii. Bacterial transmission is rarely observed [97-104], provided that donors with evidence of infection receive appropriate antibiotic therapy [97-102, 105, 106]. The duration of donor antibiotic therapy ranged from 24 to $96 \mathrm{~h}$ in different studies [97, 99, 102, 105]. Also, different authors have reported maintaining the same antibiotics administered to the donors in the transplant recipients, for periods ranging from 7 to 14 days $[98,100,105,106]$. The presence of donor infection had no impact on the survival of grafts or transplant recipients $[97-102,105,106]$.

Remarks The risk of transmission of bacterial infection from organ donors to recipients is low, and donor infection does not appear to negatively affect outcomes. The risks are lower with appropriate antibiotic therapy in the donor for at least $24 \mathrm{~h}$, followed by maintenance of the antibiotic in the recipient for 7-14 days [97-102, 105, 106]. Some donors have subclinical bacteremia at the time of organ procurement; therefore, cultures should be collected from blood and different sites in all donors, and the recipient antibiotic therapy should be directed by the results of culture [99, 107-110].

\section{Body temperature control}

16. We suggest maintaining body temperature above $35{ }^{\circ} \mathrm{C}$ in hemodynamically unstable potential donors (very low level of evidence, weak recommendation).

17. We suggest inducing moderate hypothermia (34$35{ }^{\circ} \mathrm{C}$ ) in potential donors without hemodynamic instability (low level of evidence, weak recommendation).

Summary of evidence Delayed renal graft function was evaluated in a randomized-controlled trial that compared hypothermia $\left(34-35{ }^{\circ} \mathrm{C}\right)$ versus usual management $\left(36.5-37.5{ }^{\circ} \mathrm{C}\right)$ in 370 potential donors without hemodynamic instability. The main result was a reduction in delayed renal graft function among recipients
(OR 0.62; 95\% CI 0.43-0.92). There was no difference in the number of organs transplanted per donor, adverse events, or cardiac arrest [111]. Two retrospective cohort studies nested in the randomized dopamine trial demonstrated that spontaneous donor hypothermia was associated with lower creatinine levels before organ procurement without effect on kidney graft survival [112], and with an unfavorable clinical course after heart transplant [113]. In a clinical population of post-cardiac arrest patients, i.e., patients at increased risk of hemodynamic instability, a meta-analysis of five clinical trials found a higher risk of recurrent arrest in patients with induced hypothermia $\left(<35^{\circ} \mathrm{C}\right)$ in prehospital management (RR 1.23; 95\% CI 1.02-1.48) [114].

Remarks Hypothermia is a low-cost intervention [115] associated with better renal graft function, but it can increase the risk of cardiac arrest in the potential donor $[111,114]$. The risk appears to be low in hemodynamically stable potential donors, in whom the use of hypothermia can be justified by improved graft viability. In the presence of hemodynamic instability [111], normothermia $\left(>35^{\circ} \mathrm{C}\right)$ should be maintained in potential donors to reduce the risk of cardiac arrest [114]. Induction of moderate hypothermia $\left(34-35^{\circ} \mathrm{C}\right)$ is considered a simple (application of ice packs) and inexpensive approach, but it is important to monitor core temperature, which is not available in all ICUs.

\section{Red blood cell transfusion}

18. We suggest transfusing packed red blood cells in potential donors with hemoglobin levels $<7 \mathrm{~g} / \mathrm{dL}$ (very low level of evidence, weak recommendation).

Summary of evidence The systematic literature search identified 1 descriptive observational study that evaluated function in 1884 renal grafts from 1006 brain-dead donors. Among donors, 52\% received blood transfusion. Renal grafts from transfused donors had a lower rate of delayed graft function than those from nontransfused donors $(26 \%$ vs. $34 \%, p<0.001)$. The criteria defining the need for blood transfusion were not identified [116].

Remarks Anemia can compromise oxygen transport and delivery to the organs that are intended to be preserved for transplantation. However, we are unaware of the hemoglobin concentration necessary to contribute to adequate oxygen transport and delivery in potential donors. Considering the high cost and frequent shortage of blood products for transfusion, the decision to transfuse should not differ from the usual practice in other critically ill patients. 


\section{Goal-directed protocols}

19. We suggest using a goal-directed protocol during the management of potential donors (very low level of evidence, weak recommendation).

Summary of evidence Although there is no consistent evidence about an individual treatment that will improve the number and quality of donated organs [117], observational studies have reported that combining different treatments through the application of a potential donormanagement protocol is associated with a higher organ yield for transplantation [24, 78, 118-124], lower incidence of delayed renal graft function [111], greater eligibility for lung donation [19, 28], and lower incidence of donor losses due to cardiac arrest [19, 24, 28, 119, 120]. In general, the outcomes are associated with the number of goals achieved during potential donor management, including ventilatory, hemodynamic, and endocrinemetabolic management goals [24, 78, 121-123]. In seven studies, the use of a checklist helped implement the goaldirected protocols and may have positively influenced the results [19, 28, 78, 121, 124-126].

Remarks The application of a potential donor-management protocol guided by a clinical goal-directed checklist may contribute to increasing the number of organs transplanted per donor, influence graft function, and reduce donor losses due to cardiac arrest.

\section{General considerations and future directions}

The present guideline aimed to provide parameters to optimize the clinical management of potential donors based on the available evidence, aiming to improve the quality of organs for transplantation and to reduce donor losses. However, it is well known that it may take years for a large-scale translation of the best scientific evidence into effective practice. Thus, establishing clinical protocols can help to reduce the time required to incorporate best practices. The use of a goal-directed checklist can play an important role in the adjustment of approaches and adherence to the best evidence in complex procedures [127-130].

This guideline evaluated a broad volume of treatments and we performed rigorous $\mathrm{PICO}$-driven research to provide the recommendations based on standardized rapid review methods $[9,10]$. Potential limitations are the low or very low certainty in the evidence identified for many of the questions, and indirect evidence that did not change after the systematic review update. However, management recommendations are consistent with similar documents recently published [11, 131, 132].
Several challenges regarding ethical, infrastructure, and operational issues are faced while planning and conducting studies that involve potential organ donors, which results in few randomized clinical trials [133]. The scarcity of studies with such methodological strength implies uncertainties about some interventions such as low-dose dopamine and moderate hypothermia, which, despite appearing to be related to renal graft benefit, may result in cardiac arrhythmias and hemodynamic instability. In this context, developing clinical trials in this field of medical knowledge may be helpful to understand some important aspects in the management of the potential organ donor.

Some observational studies have reported that the application of a checklist to guide the management of brain-dead potential donors may help to reduce the rate of cardiac arrest in potential donors and increase the number of organs recovered per donor $[24,78,119,121$, $122,124,126,134,135]$. In this context, we used the main recommendations of the present guideline to develop an evidence-based clinical goal-directed checklist (Additional file 3) with the purpose of providing transplant coordinators and ICU professionals with essential information to optimize the care of potential donors.

However, because the available studies highlighting the role of potential donor-management checklists are observational, there is insufficient evidence to support the systematic use of checklists in the management of potential donors. Therefore, we proposed the Donation Network to Optimize Organ Recovery Study (DONORS; NCT03179020), which is a parallel cluster randomizedcontrolled multicenter trial that aims to test the effectiveness of the implementation of a checklist containing goals and recommendations of care in reducing organ donor losses due to cardiac arrest and increasing the number of organs recovered per donor [136].

The implementation of the checklist should be preceded by the appropriate training of intensive care teams and transplant coordinators. We suggest applying the checklist at the bedside immediately after the first clinical examination for the diagnosis of brain death, repeating the application, ideally, every $6 \mathrm{~h}$ until organ procurement for transplantation. We also suggest that a member of the transplant coordination office or a designated professional of the ICU or emergency department applies the checklist at the bedside. The same individual will also be responsible for personally prompting the physician in charge to modify the clinical management if any inappropriate aspect of care, according to the checklist, is noted. 


\section{Supplementary information}

Supplementary information accompanies this paper at https://doi. org/10.1186/s13613-020-00787-0.

Additional file 1. Working group and contributions of each participant.

Additional file 2. Declaration of competing interests.

Additional file 3. Checklist for clinical management of brain-dead potential organ donor.

\section{Acknowledgements}

The authors would like to thank the Brazilian Ministry of Health and the General Coordination Office of the National Transplant System (CGSNT), as well as Moinhos de Vento Hospital, the Brazilian Association of Organ Transplantation (ABTO), the Brazilian Association of Intensive Care Medicine (AMIB) Committee for Organ Donation for Transplant, and the Brazilian Research in Intensive Care Network (BRICNet) for their support.

\section{Authors' contributions}

All authors, except for AR, DFSP, FDP, RCM, and RRN, participated in at least one of the expert panels. All authors read and approved the final manuscript. The detailed contribution of each author is presented in Additional file 1.

\section{Funding}

This guideline was funded by the Brazilian Ministry of Health through the Programa de Apoio ao Desenvolvimento Institucional do Sistema Único de Saúde (PROADI-SUS). The funding body has no role in the coordination of the guideline.

\section{Availability of data and materials}

All relevant data are within the paper and its additional files.

\section{Ethics approval and consent to participate}

Not applicable.

\section{Consent for publication}

Not applicable.

\section{Competing interests}

The competing interests of each author are presented in Additional file 2.

\section{Author details}

${ }^{1}$ Hospital Moinhos de Vento (HMV), R. Ramiro Barcelos, 910, Porto Alegre, RS 90035000, Brazil. ${ }^{2}$ Hospital Municipal São José (HMSJ), Joinville, SC, Brazil. ${ }^{3}$ Centro Hospitalar Unimed, Joinville, SC, Brazil. ${ }^{4}$ Hospital do Coração (HCor), R. Desembargador Eliseu Guilherme, 147, São Paulo, SP 04004030, Brazil. ${ }^{5}$ Universidade da Região de Joinville (UNIVILLE), R. Paulo Malschitzki, 10, Joinville, SC 89219710, Brazil. ${ }^{6}$ Clínica de Nefrologia de Joinville, R. Plácido Gomes, 370, Joinville, SC 89202-050, Brazil. ${ }^{7}$ Hospital de Clínicas de Porto Alegre (HCPA), R. Ramiro Barcelos, 2350, Porto Alegre, RS 90035007, Brazil. ${ }^{8}$ Universidade Federal de Ciências da Saúde de Porto Alegre (UFCSPA), Sarmento Leite, 245, Porto Alegre, RS 90050-170, Brazil. ${ }^{9}$ Hospital de Pronto de Socorro (HPS), Porto Alegre, RS, Brazil. ${ }^{10}$ General Coordination Office of the National Transplant System, Brazilian Ministry of Health, Esplanada dos Ministérios, Bloco G, Edifício Sede, Brasília, DF 70058900, Brazil. ${ }^{11}$ Faculdade de Medicina, Universidade de São Paulo (USP), Av. Dr, Arnaldo 455, Sala 3206, São Paulo, SP 01246903, Brazil. ${ }^{12}$ Universidade do Extremo Sul Catarinense (UNESC), Av. Universitária, 1105, Criciúma, SC 88806000, Brazil. ${ }^{13}$ Intensive Care Unit, Hospital São José, R. Cel. Pedro Benedet, 630, Criciúma, SC 88801-250, Brazil. ${ }^{14}$ National Institute of Infectious Disease Evandro Chagas, Fundação Oswaldo Cruz (FIOCRUZ), Av. Brasil, 4365, Rio de Janeiro, RJ 21040360, Brazil. ${ }^{15}$ Instituto D'Or de Pesquisa e Ensino (IDOR), R. Diniz Cordeiro, 30, Rio de Janeiro, RJ 22281100, Brazil. ${ }^{16}$ Hospital São Paulo (HU), Universidade Federal de São Paulo (UNIFESP), R. Napoleão de Barros 737, São Paulo, SP 04024002, Brazil. ${ }^{17}$ Organização de Procura de Órgãos e Tecidos de Santa Catarina (OPO/SC), Rua Esteves Júnior, 390, Florianópolis, SC 88015130, Brazil. ${ }^{18}$ Hospital Sírio-Libanês, R. Dona Adma Jafet, 115, São Paulo, SP, Brazil. ${ }^{19}$ Universidade Federal do Rio Grande do Sul (UFRGS), Ramiro Barcelos, 2350, Porto Alegre, RS 90035007, Brazil. ${ }^{20}$ Faculdade de Medicina de São José do Rio Preto, Av Faria Lima, 5544, São José do Rio Preto, SP 15090000, Brazil. ${ }^{21}$ National Institute for Health Technology Assessment, UFRGS, Rua Ramiro Barcelos, 2350, Porto Alegre, RS 90035903 , Brazil. ${ }^{22}$ Department of Health Research Methods, Evidence, and Impact (HEI), McMaster University, 1280 Main St W, Hamilton, ON, Canada.

Received: 3 August 2020 Accepted: 1 December 2020

Published online: 14 December 2020

\section{References}

1. Tullius SG, Rabb H. Improving the supply and quality of deceaseddonor organs for transplantation. N Engl J Med. 2018;378:1920-9. https ://doi.org/10.1056/NEJMra1507080.

2. The Madrid resolution on organ donation and transplantation. national responsibility in meeting the needs of patients, guided by the $\mathrm{WHO}$ principles. Transplantation. 2011;91(Suppl 11):S29-31. https://doi. org/10.1097/01.tp.0000399131.74618.a5.

3. Dominguez-Gil B, Delmonico FL, Shaheen FA, Matesanz R, O'Connor K, Minina M, et al. The critical pathway for deceased donation: reportable uniformity in the approach to deceased donation. Transpl Int. 2011;24:373-8. https://doi.org/10.1111/j.1432-2277.2011.01243.x.

4. DuBose J, Salim A. Aggressive organ donor management protocol. J Intensive Care Med. 2008;23:367-75. https://doi.org/10.1177/08850 66608324208.

5. Powner D. Aggressive donor care-to what end? J Intensive Care Med. 2008;23:409-11. https://doi.org/10.1177/0885066608324198.

6. Westphal GA, Caldeira Filho M, Vieira KD, Zaclikevis VR, Bartz MC, Wanzuita R, et al. Guidelines for potential multiple organ donors (adult): part I. Overview and hemodynamic support. Rev Bras Ter Intensiva. 2011;23:255-68

7. Westphal GA, Caldeira Filho M, Vieira KD, Zaclikevis VR, Bartz MC, Wanzuita R, et al. Guidelines for potential multiple organ donors (adult): part II. Mechanical ventilation, endocrine metabolic management, hematological and infectious aspects. Rev Bras Ter Intensiva. 2011;23:269-82.

8. Westphal GA, Caldeira Filho M, Vieira KD, Zaclikevis VR, Bartz MC, Wanzuita R, et al. Guidelines for potential multiple organ donors (adult). Part III: organ-specific recommendations. Rev Bras Ter Intensiva. 2011:23:410-25.

9. Schunemann HJ, Moja L. Reviews: rapid! Rapid! Rapid!... and systematic. Syst Rev. 2015:4:4. https://doi.org/10.1186/2046-4053-4-4.

10. Haby MM, Chapman E, Clark R, Barreto J, Reveiz L, Lavis JN. Designing a rapid response program to support evidence-informed decisionmaking in the Americas region: using the best available evidence and case studies. Implement Sci. 2016;11:117. https://doi.org/10.1186/s1301 2-016-0472-9.

11. Kotloff RM, Blosser S, Fulda GJ, Malinoski D, Ahya VN, Angel L, et al. Management of the potential organ donor in the ICU: Society of Critical Care Medicine/American College of Chest Physicians/Association of Organ Procurement Organizations Consensus Statement. Crit Care Med. 2015;43:1291-325. https://doi.org/10.1097/CCM.0000000000 000958.

12. Guyatt $G H$, Oxman AD, Vist GE, Kunz R, Falck-Ytter $Y$, Alonso-Coello P, et al. GRADE: an emerging consensus on rating quality of evidence and strength of recommendations. BMJ. 2008;336:924-6. https://doi. org/10.1136/bmj.39489.470347.AD.

13. Mascia L, Zavala E, Bosma K, Pasero D, Decaroli D, Andrews P, et al. High tidal volume is associated with the development of acute lung injury after severe brain injury: an international observational study. Crit Care Med. 2007;35:1815-20. https://doi.org/10.1097/01.CCM.0000275269 77467.DF.

14. Mascia L, Pasero D, Slutsky AS, Arguis MJ, Berardino M, Grasso S, et al. Effect of a lung protective strategy for organ donors on eligibility and availability of lungs for transplantation: a randomized controlled trial. JAMA. 2010;304:2620-7. https://doi.org/10.1001/jama.2010.1796.

15. Lebovitz DJ, Reis K, Yun J, Herman L, McCurry KR. An aggressive lung recruitment protocol increases the percentage of lung donors with no increased adverse effect in lung recipients: 3173 . Transplantation. 2010:90:356. 
16. Noiseux N, Nguyen BK, Marsolais P, Dupont J, Simard L, Houde I, et al. Pulmonary recruitment protocol for organ donors: a new strategy to improve the rate of lung utilization. Transplant Proc. 2009;41:3284-9. https://doi.org/10.1016/j.transproceed.2009.08.041.

17. Gabbay E, Williams TJ, Griffiths AP, Macfarlane LM, Kotsimbos TC, Esmore DS, et al. Maximizing the utilization of donor organs offered for lung transplantation. Am J Respir Crit Care Med. 1999;160:265-71. https:// doi.org/10.1164/ajrccm.160.1.9811017.

18. Gattinoni L, Carlesso E, Brazzi L, Caironi P. Positive end-expiratory pressure. Curr Opin Crit Care. 2010;16:39-44. https://doi.org/10.1097/ MCC.0b013e3283354723.

19. Minambres E, Coll E, Duerto J, Suberviola B, Mons R, Cifrian JM, et al. Effect of an intensive lung donor-management protocol on lung transplantation outcomes. J Heart Lung Transplant. 2014;33:178-84. https:// doi.org/10.1016/j.healun.2013.10.034.

20. Angel LF, Levine DJ, Restrepo MI, Johnson S, Sako E, Carpenter A, et al. Impact of a lung transplantation donor-management protocol on lung donation and recipient outcomes. Am J Respir Crit Care Med. 2006;174:710-6. https://doi.org/10.1164/rccm.200603-4320C.

21. Writing Group for the Alveolar Recruitment for Acute Respiratory Distress Syndrome Trial I, Cavalcanti AB, Suzumura EA, Laranjeira LN, Paisani DM, Damiani LP, et al. Effect of lung recruitment and Titrated Positive End-Expiratory Pressure (PEEP) vs Low PEEP on mortality in patients with acute respiratory distress syndrome: a randomized clinical trial. JAMA. 2017;318:1335-45. https://doi.org/10.1001/jama.2017.14171

22. Gruenberger T, Steininger R, Sautner T, Mittlbock M, Muhlbacher F. Influence of donor criteria on postoperative graft function after orthotopic liver transplantation. Transpl Int. 1994;7(Suppl 1):S672-4. https://doi. org/10.1111/j.1432-2277.1994.tb01470.x.

23. delaTorre AN, Kuo PC, Plotkin JS, Ridge LA, Howell CD, Bartlett ST, et al. Influence of donor base deficit status on recipient outcomes in liver transplantation. Transplant Proc. 1997;29:474. https://doi.org/10.1016/ s0041-1345(96)00627-6.

24. Westphal GA, Coll E, deSouza RL, Wagner S, Montemezzo A, Cani de Souza FC, et al. Positive impact of a clinical goal-directed protocol on reducing cardiac arrests during potential brain-dead donor maintenance. Crit Care. 2016;20:323. https://doi.org/10.1186/s1305 4-016-1484-1.

25. Murugan R, Venkataraman R, Wahed AS, Elder M, Carter M, Madden NJ, et al. Preload responsiveness is associated with increased interleukin-6 and lower organ yield from brain-dead donors. Crit Care Med. 2009;37:2387-93. https://doi.org/10.1097/CCM.0b013e3181a960d6.

26. Al-Khafaji A, Elder M, Lebovitz DJ, Murugan R, Souter M, Stuart S, et al. Protocolized fluid therapy in brain-dead donors: the multicenter randomized MOnIToR trial. Intensive Care Med. 2015;41:418-26. https://doi. org/10.1007/s00134-014-3621-0.

27. Abdelnour T, Rieke S. Relationship of hormonal resuscitation therapy and central venous pressure on increasing organs for transplant. J Heart Lung Transplant. 2009;28:480-5. https://doi.org/10.1016/j.healu n.2009.01.018

28. Minambres E, Perez-Villares JM, Chico-Fernandez M, Zabalegui A, Duenas-Jurado JM, Misis M, et al. Lung donor treatment protocol in brain dead-donors: a multicenter study. J Heart Lung Transplant. 2015;34:773-80. https://doi.org/10.1016/j.healun.2014.09.024.

29. Minambres E, Perez-Villares JM, Terceros-Almanza L, Duenas-Jurado JM, Zabalegui A, Misis M, et al. An intensive lung donor treatment protocol does not have negative influence on other grafts: a multicentre study. Eur J Cardiothorac Surg. 2016;49:1719-24. https://doi.org/10.1093/ejcts /ezv454.

30. Cecconi M, De Backer D, Antonelli M, Beale R, Bakker J, Hofer C, et al. Consensus on circulatory shock and hemodynamic monitoring. Task force of the European Society of Intensive Care Medicine. Intensive Care Med. 2014;40:1795-815. https://doi.org/10.1007/s00134-014-3525-z.

31. Schnuelle P, Lorenz D, Mueller A, Trede M, Van Der Woude FJ. Donor catecholamine use reduces acute allograft rejection and improves graft survival after cadaveric renal transplantation. Kidney Int. 1999;56:73846. https://doi.org/10.1046/j.1523-1755.1999.00567.x.

32. Schnuelle P, Berger S, de Boer J, Persijn G, van der Woude FJ. Effects of catecholamine application to brain-dead donors on graft survival in solid organ transplantation. Transplantation. 2001;72:455-63. https:// doi.org/10.1097/00007890-200108150-00017.

33. von Ziegler F, Helbig S, KreissI N, Meiser B, Becker A, Kaczmarek I. Norepinephrine versus dopamine pretreatment of potential heart donors-impact on long-term outcome. Ann Transplant. 2013;18:320-6. https://doi.org/10.12659/AOT.883960.

34. Dictus C, Vienenkoetter B, Esmaeilzadeh M, Unterberg A, Ahmadi R. Critical care management of potential organ donors: our current standard. Clin Transplant. 2009;23(Suppl 21):2-9. https://doi.org/10.1 111/j.1399-0012.2009.01102.x.

35. Wood KE, Becker BN, McCartney JG, D'Alessandro AM, Coursin DB. Care of the potential organ donor. N Engl J Med. 2004;351(26):27309. https://doi.org/10.1056/NEJMra013103.

36. Marik PE, Baram M, Vahid B. Does central venous pressure predict fluid responsiveness? A systematic review of the literature and the tale of seven mares. Chest. 2008;134:172-8. https://doi.org/10.1378/ chest.07-2331.

37. Eskesen TG, Wetterslev M, Perner A. Systematic review including re-analyses of 1148 individual data sets of central venous pressure as a predictor of fluid responsiveness. Intensive Care Med. 2016;42:32432. https://doi.org/10.1007/s00134-015-4168-4.

38. Marik PE, Cavallazzi R, Vasu T, Hirani A. Dynamic changes in arterial waveform derived variables and fluid responsiveness in mechanically ventilated patients: a systematic review of the literature. Crit Care Med. 2009;37:2642-7. https://doi.org/10.1097/CCM.0b013e3181 a590da.

39. Rui $Q$, Jiang $Y$, Chen $M$, Zhang $N$, Yang $H$, Zhou Y. Dopamine versus norepinephrine in the treatment of cardiogenic shock: a PRISMAcompliant meta-analysis. Medicine. 2017;96:e8402. https://doi. org/10.1097/MD.0000000000008402.

40. Benck U, Hoeger S, Brinkkoetter PT, Gottmann U, Doenmez D, Boesebeck D, et al. Effects of donor pre-treatment with dopamine on survival after heart transplantation: a cohort study of heart transplant recipients nested in a randomized controlled multicenter trial. J Am Coll Cardiol. 2011;58:1768-77. https://doi.org/10.1016/j. jacc.2011.05.060.

41. Schnuelle P, Gottmann U, Hoeger S, Boesebeck D, Lauchart W, Weiss C, et al. Effects of donor pretreatment with dopamine on graft function after kidney transplantation: a randomized controlled trial. JAMA. 2009;302:1067-75. https://doi.org/10.1001/jama.2009.1310.

42. Schnuelle P, Schmitt WH, Weiss C, Habicht A, Renders L, Zeier M, et al. Effects of dopamine donor pretreatment on graft survival after kidney transplantation: a randomized trial. Clin J Am Soc Nephrol. 2017;12:493-501. https://doi.org/10.2215/CJN.07600716.

43. Benck U, Jung M, Kruger B, Grimm A, Weiss C, Yard BA, et al. Donor Dopamine Does Not Affect Liver Graft Survival: evidence of Safety From a Randomized Controlled Trial. Liver Transpl. 2018;24:1336-45. https:// doi.org/10.1002/It.25301.

44. Iwai A, Sakano T, Uenishi M, Sugimoto H, Yoshioka T, Sugimoto T. Effects of vasopressin and catecholamines on the maintenance of circulatory stability in brain-dead patients. Transplantation. 1989:48:613-7.

45. Kinoshita Y, Yahata K, Yoshioka T, Onishi S, Sugimoto T. Long-term renal preservation after brain death maintained with vasopressin and epinephrine. Transpl Int. 1990;3:15-8. https://doi.org/10.1007/bf00333196.

46. Pennefather SH, Bullock RE, Mantle D, Dark JH. Use of low dose arginine vasopressin to support brain-dead organ donors. Transplantation. 1995;59:58-62. https://doi.org/10.1097/00007890-199501150-00011.

47. Plurad DS, Bricker S, Neville A, Bongard F, Putnam B. Arginine vasopressin significantly increases the rate of successful organ procurement in potential donors. Am J Surg. 2012;204:856-60. https://doi.org/10.1016/j. amjsurg.2012.05.011.

48. Chen JM, Cullinane S, Spanier TB, Artrip JH, John R, Edwards NM, et al. Vasopressin deficiency and pressor hypersensitivity in hemodynamically unstable organ donors. Circulation. 1999;100:244-6. https://doi. org/10.1161/01.cir.100.suppl_2.ii-244.

49. Katz K, Lawler J, Wax J, O'Connor R, Nadkarni V. Vasopressin pressor effects in critically ill children during evaluation for brain death and organ recovery. Resuscitation. 2000;47:33-40. https://doi.org/10.1016/ s0300-9572(00)00196-9.

50. Benck U, Gottmann U, Hoeger S, Lammert A, Rose D, Boesebeck D, et al. Donor desmopressin is associated with superior graft survival after 
kidney transplantation. Transplantation. 2011;92:1252-8. https://doi. org/10.1097/TP.0b013e318236cd4c.

51. Shemie SD, Ross H, Pagliarello J, Baker AJ, Greig PD, Brand T, et al. Organ donor management in Canada: recommendations of the forum on Medical Management to Optimize Donor Organ Potential. CMAJ. 2006;174:S13-32. https://doi.org/10.1503/cmaj.045131.

52. Gramm HJ, Meinhold H, Bickel U, Zimmermann J, von Hammerstein B, Keller $F$, et al. Acute endocrine failure after brain death? Transplantation. 1992:54:851-7. https://doi.org/10.1097/00007890-199211000-00016.

53. Fiser DH, Jimenez JF, Wrape V, Woody R. Diabetes insipidus in children with brain death. Crit Care Med. 1987;15:551-3. https://doi. org/10.1097/00003246-198706000-00002.

54. Follette DM, Rudich SM, Babcock WD. Improved oxygenation and increased lung donor recovery with high-dose steroid administration after brain death. J Heart Lung Transplant. 1998;17:423-9. https://doi. org/10.1007/s801090000086.

55. Dhar R, Cotton C, Coleman J, Brockmeier D, Kappel D, Marklin G, et al. Comparison of high- and low-dose corticosteroid regimens for organ donor management. J Crit Care. 2013;28(111):e1-7. https://doi. org/10.1007/s801090000086.

56. Jafari R, Aflatoonian R, Falak R, Pourmand G, Dehghani S, Mortazavi M, et al. Down-regulation of inflammatory signaling pathways despite up-regulation of Toll-like receptors; the effects of corticosteroid therapy in brain-dead kidney donors, a double-blind, randomized, controlled trial. Mol Immunol. 2018;94:36-44. https://doi.org/10.1016/j.molim m.2017.12.012.

57. Dupuis S, Amiel JA, Desgroseilliers M, Williamson DR, Thiboutot Z, Serri $\mathrm{K}$, et al. Corticosteroids in the management of brain-dead potential organ donors: a systematic review. Br J Anaesth. 2014;113:346-59. https ://doi.org/10.1093/bja/aeu154.

58. Pinsard M, Ragot S, Mertes PM, Bleichner JP, Zitouni S, Cook F, et al. Interest of low-dose hydrocortisone therapy during brain-dead organ donor resuscitation: the CORTICOME study. Crit Care. 2014;18:R158. https://doi.org/10.1186/cc13997.

59. Venkateswaran RV, Steeds RP, Quinn DW, Nightingale P, Wilson IC, Mascaro JG, et al. The haemodynamic effects of adjunctive hormone therapy in potential heart donors: a prospective randomized doubleblind factorially designed controlled trial. Eur Heart J. 2009;30:1771-80. https://doi.org/10.1093/eurheartj/ehp086.

60. Perez-Blanco A, Caturla-Such J, Canovas-Robles J, Sanchez-Paya J. Efficiency of triiodothyronine treatment on organ donor hemodynamic management and adenine nucleotide concentration. Intensive Care Med. 2005;31:943-8. https://doi.org/10.1007/s00134-005-2662-9.

61. Jeevanandam V. Triiodothyronine: spectrum of use in heart transplantation. Thyroid. 1997;7:139-45. https://doi.org/10.1089/thy.1997.7.139.

62. Goarin JP, Cohen S, Riou B, Jacquens Y, Guesde R, Le Bret F, et al. The effects of triiodothyronine on hemodynamic status and cardiac function in potential heart donors. Anesth Analg. 1996;83:41-7. https://doi. org/10.1097/00000539-199607000-00008.

63. Randell TT, Hockerstedt KA. Triiodothyronine treatment in brain-dead multiorgan donors-a controlled study. Transplantation. 1992;54:736-8. https://doi.org/10.1097/00007890-199210000-00034.

64. Garcia-Fages LC, Antolin M, Cabrer C, Talbot R, Alcaraz A, Lozano F, et al. Effects of substitutive triiodothyronine therapy on intracellular nucleotide levels in donor organs. Transplant Proc. 1991;23:2495-6.

65. Mariot J, Jacob F, Voltz C, Perrier JF, Strub P. Value of hormonal treatment with triiodothyronine and cortisone in brain dead patients. Ann $\mathrm{Fr}$ Anesth Reanim. 1991;10:321-8. https://doi.org/10.1007/s801090000 086.

66. Macdonald PS, Aneman A, Bhonagiri D, Jones D, O'Callaghan G, Silvester W, et al. A systematic review and meta-analysis of clinical trials of thyroid hormone administration to brain dead potential organ donors. Crit Care Med. 2012;40:1635-44. https://doi.org/10.1097/CCM.0b013 e3182416ee7.

67. Rech TH, Moraes RB, Crispim D, Czepielewski MA, Leitao CB. Management of the brain-dead organ donor: a systematic review and metaanalysis. Transplantation. 2013;95:966-74. https://doi.org/10.1097/ TP.0b013e318283298e.

68. Dhar R, Stahlschmidt E, Marklin G. A randomized trial of intravenous thyroxine for brain-dead organ donors with impaired cardiac function.
Prog Transplant. 2020;30:48-55. https://doi.org/10.1177/1526924819 893295.

69. Dhar R, Stahlschmidt E, Yan Y, Marklin G. A randomized trial comparing triiodothyronine (T3) with thyroxine (T4) for hemodynamically unstable brain-dead organ donors. Clin Transplant. 2019;33:e13486. https://doi. org/10.1111/ctr.13486.

70. Hesse UJ, Sutherland DE. Influence of serum amylase and plasma glucose levels in pancreas cadaver donors on graft function in recipients. Diabetes. 1989;38(Suppl 1):1-3. https://doi.org/10.2337/diab.38.1.s1.

71. Gores PF, Gillingham KJ, Dunn DL, Moudry-Munns KC, Najarian JS, Sutherland DE. Donor hyperglycemia as a minor risk factor and immunologic variables as major risk factors for pancreas allograft loss in a multivariate analysis of a single institution's experience. Ann Surg. 1992;215:217-30. https://doi.org/10.1097/00000658-199203000-00005.

72. Masson F, Thicoipe M, Gin H, de Mascarel A, Angibeau RM, FavarelGarrigues JF, et al. The endocrine pancreas in brain-dead donors. A prospective study in 25 patients. Transplantation. 1993;56:363-7. https ://doi.org/10.1097/00007890-199308000-00022.

73. Odorico JS, Heisey DM, Voss BJ, Steiner DS, Knechtle SJ, D'Alessandro $A M$, et al. Donor factors affecting outcome after pancreas transplantation. Transplant Proc. 1998;30:276-7. https://doi.org/10.1016/s0041 -1345(97)01263-3.

74. Shaffer D, Madras PN, Sahyoun Al, Simpson MA, Monaco AP. Cadaver donor hyperglycemia does not impair long-term pancreas allograft survival or function. Transplant Proc. 1994;26:439-40.

75. Blasi-Ibanez A, Hirose R, Feiner J, Freise C, Stock PG, Roberts JP, et al. Predictors associated with terminal renal function in deceased organ donors in the intensive care unit. Anesthesiology. 2009;110:333-41. https://doi.org/10.1097/ALN.0b013e318194ca8a.

76. Perez-Protto SE, Reynolds LF, Dalton JE, Taketomi T, Irefin SA, Parker BM, et al. Deceased donor hyperglycemia and liver graft dysfunction. Prog Transplant. 2014;24:106-12. https://doi.org/10.7182/pit2014737.

77. Sally MB, Ewing T, Crutchfield M, Patel MS, Raza S, DeLaCruz S, et al. Determining optimal threshold for glucose control in organ donors after neurologic determination of death: a United Network for Organ Sharing Region 5 Donor Management Goals Workgroup prospective analysis. J Trauma Acute Care Surg. 2014;76:62-8. https://doi. org/10.1097/ta.0b013e3182ab0d9b.

78. Patel MS, Zatarain J, De La Cruz S, Sally MB, Ewing T, Crutchfield M, et al. The impact of meeting donor management goals on the number of organs transplanted per expanded criteria donor: a prospective study from the UNOS Region 5 Donor Management Goals Workgroup. JAMA Surg. 2014;149:969-75. https://doi.org/10.1001/jamasurg.2014.967.

79. Khosravi MB, Firoozifar M, Ghaffaripour S, Sahmeddini MA, Eghbal MH. Early outcomes of liver transplants in patients receiving organs from hypernatremic donors. Exp Clin Transplant. 2013;11:537-40. https://doi. org/10.6002/ect.2012.0274

80. Kaseje N, McLin V, Toso C, Poncet A, Wildhaber BE. Donor hypernatremia before procurement and early outcomes following pediatric liver transplantation. Liver Transpl. 2015;21:1076-81. https://doi.org/10.1002/ It.24145.

81. Mangus RS, Fridell JA, Vianna RM, Milgrom ML, Chestovich P, Vandenboom C, et al. Severe hypernatremia in deceased liver donors does not impact early transplant outcome. Transplantation. 2010;90:438-43. https://doi.org/10.1097/TP.0b013e3181e764c0.

82. Kaczmarek I, Tenderich G, Groetzner J, Deutsch MA, Schulz U, BeirasFernandez $A$, et al. The controversy of donor serum sodium levels in heart transplantation - a multicenter experience. Thorac Cardiovasc Surg. 2006;54:313-6. https://doi.org/10.1055/s-2006-923889.

83. Totsuka E, Dodson F, Urakami A, Moras N, Ishii T, Lee MC, et al. Influence of high donor serum sodium levels on early postoperative graft function in human liver transplantation: effect of correction of donor hypernatremia. Liver Transpl Surg. 1999;5:421-8. https://doi.org/10.1002/ It.500050510.

84. Dawwas MF, Lewsey JD, Neuberger JM, Gimson AE. The impact of serum sodium concentration on mortality after liver transplantation: a cohort multicenter study. Liver Transpl. 2007;13:1115-24. https://doi. org/10.1002/lt.21154.

85. Cywinski JB, Mascha E, Miller C, Eghtesad B, Nakagawa S, Vincent JP, et al. Association between donor-recipient serum sodium differences 
and orthotopic liver transplant graft function. Liver Transpl. 2008;14:5965. https://doi.org/10.1002/lt.21305.

86. Mousavi SA, Shahabi S, Mostafapour E, Purfakharan M, Fereshtehnejad SM, Amini J, et al. Comparison of the serum electrolyte levels among patients died and survived in the intensive care unit. Tanaffos. 2012;11:36-42.

87. Chen M, Sun R, Hu B. The influence of serum magnesium level on the prognosis of critically ill patients. Zhonghua Wei Zhong Bing Ji Jiu Yi Xue. 2015;27:213-7. https://doi.org/10.3760/cma.j.i ssn.2095-4352.2015.03.011.

88. Kumar S, Honmode A, Jain S, Bhagat V. Does magnesium matter in patients of Medical Intensive Care Unit: a study in rural Central India. Indian J Crit Care Med. 2015;19:379-83. https://doi.org/10.4103/09725229.160272.

89. Velissaris D, Karamouzos V, Pierrakos C, Aretha D, Karanikolas M. Hypomagnesemia in critically ill sepsis patients. J Clin Med Res. 2015;7:911-8. https://doi.org/10.14740/jocmr2351w.

90. Thel MC, Armstrong AL, MCNulty SE, Califf RM, O'Connor CM. Randomised trial of magnesium in in-hospital cardiac arrest. Duke Internal Medicine Housestaff. Lancet. 1997;350:1272-6. https://doi.org/10.1016/ s0140-6736(97)05048-4.

91. Smith LF, Heagerty AM, Bing RF, Barnett DB. Intravenous infusion of magnesium sulphate after acute myocardial infarction: effects on arrhythmias and mortality. Int J Cardiol. 1986;12:175-83. https://doi. org/10.1016/0167-5273(86)90239-1.

92. Alves SC, Tomasi CD, Constantino L, Giombelli V, Candal R, Bristot Mde L, et al. Hypomagnesemia as a risk factor for the non-recovery of the renal function in critically ill patients with acute kidney injury. Nephrol Dial Transplant. 2013;28:910-6. https://doi.org/10.1093/ndt/gfs268.

93. Powner DJ. Factors during donor care that may affect liver transplantation outcome. Prog Transplant. 2004;14:241-7. https://doi.org/10.7182/ prtr.14.3.d36p8205k2025274.

94. Adam R, Reynes M, Bao YM, Astarcioglu I, Azoulay D, Chiche L, et al. Impact of glycogen content of the donor liver in clinical liver transplantation. Transplant Proc. 1993:25:1536-7.

95. Powner DJ, Bernstein IM. Extended somatic support for pregnant women after brain death. Crit Care Med. 2003;31:1241-9. https://doi. org/10.1097/01.CCM.0000059643.45027.96.

96. Dominguez-Roldan JM, Murillo-Cabezas F, Santamaria-Mifsut JL, Munoz-Sanchez A, Villen-Nieto J, Barrera-Chacon JM. Changes in resting energy expenditure after development of brain death. Transplant Proc. 1995:27:2397-8

97. Little DM, Farrell JG, Cunningham PM, Hickey DP. Donor sepsis is not a contraindication to cadaveric organ donation. QJM. 1997;90:641-2. https://doi.org/10.1093/qjmed/90.10.641.

98. Zibari GB, Lipka J, Zizzi H, Abreo KD, Jacobbi L, McDonald JC. The use of contaminated donor organs in transplantation. Clin Transplant. 2000;14:397-400. https://doi.org/10.1034/j.1399-0012.2000.14040702.x.

99. Lumbreras C, Sanz F, Gonzalez A, Perez G, Ramos MJ, Aguado JM, et al. Clinical significance of donor-unrecognized bacteremia in the outcome of solid-organ transplant recipients. Clin Infect Dis. 2001;33:722-6. https ://doi.org/10.1086/322599.

100. Caballero F, Lopez-Navidad A, Perea M, Cabrer C, Guirado L, Sola R Successful liver and kidney transplantation from cadaveric donors with left-sided bacterial endocarditis. Am J Transplant. 2005;5:781-7. https:// doi.org/10.1111/j.1600-6143.2005.00773.x.

101. Len O, Gavalda J, Blanes M, Montejo M, San Juan R, Moreno A, et al. Donor infection and transmission to the recipient of a solid allograft. Am J Transplant. 2008;8:2420-5. https://doi.org/10.111 1/j.1600-6143.2008.02397.x.

102. Sozen H, Fidan K, Mahli A, Singin E, Buyan N, Sindel S, et al. Successful solid organ transplantation from septicemic cadaveric donors: case report. Transplant Proc. 2008;40:299-301. https://doi.org/10.1016/j.trans proceed.2007.11.044.

103. Lin TL, Kuo SC, Yeh CH, Chan YC, Lin YH, Li WF, et al. Donor-transmitted bacterial infection in deceased donor liver transplantation: experience of Southern Taiwan Medical Center. Transplant Proc. 2018;50:2711-4. https://doi.org/10.1016/j.transproceed.2018.04.017.

104. Corman Dincer P, Tore Altun G, Birtan D, Arslantas R, Sarici Mert N, Ozdemir I, et al. Incidence and risk factors for systemic infection in deceased donors. Transplant Proc. 2019;51:2195-7. https://doi. org/10.1016/j.transproceed.2019.03.054.

105. Kubak BM, Gregson AL, Pegues DA, Leibowitz MR, Carlson M, Marelli $D$, et al. Use of hearts transplanted from donors with severe sepsis and infectious deaths. J Heart Lung Transplant. 2009;28:260-5. https://doi. org/10.1016/j.healun.2008.11.911.

106. Outerelo C, Gouveia R, Mateus A, Cruz P, Oliveira C, Ramos A. Infected donors in renal transplantation: expanding the donor pool. Transplant Proc. 2013:45:1054-6. https://doi.org/10.1016/j.transproce ed.2013.02.014.

107. Freeman RB, Giatras I, Falagas ME, Supran S, O'Connor K, Bradley J, et al. Outcome of transplantation of organs procured from bacteremic donors. Transplantation. 1999;68:1107-11. https://doi. org/10.1097/00007890-199910270-00008.

108. Cerutti E, Stratta C, Romagnoli R, Serra R, Lepore M, Fop F, et al. Bacterial- and fungal-positive cultures in organ donors: clinical impact in liver transplantation. Liver Transpl. 2006;12:1253-9. https://doi.org/10.1002/ It.20811.

109. Angelis M, Cooper JT, Freeman RB. Impact of donor infections on outcome of orthotopic liver transplantation. Liver Transpl. 2003;9:451-62. https://doi.org/10.1053/jts.2003.50094.

110. Ruiz I, Gavalda J, Monforte V, Len O, Roman A, Bravo C, et al. Donor-tohost transmission of bacterial and fungal infections in lung transplantation. Am JTransplant. 2006;6:178-82. https://doi.org/10.111 1/j.1600-6143.2005.01145.x.

111. Niemann CU, Feiner J, Swain S, Bunting S, Friedman M, Crutchfield M, et al. Therapeutic hypothermia in deceased organ donors and kidneygraft function. N Engl J Med. 2015;373:405-14. https://doi.org/10.1056/ NEJMoa1501969.

112. Schnuelle P, Mundt HM, Druschler F, Schmitt WH, Yard BA, Kramer BK, et al. Impact of spontaneous donor hypothermia on graft outcomes after kidney transplantation. Am J Transplant. 2018;18:704-14. https:// doi.org/10.1111/ajt.14541.

113. Schnuelle P, Benck U, Kramer BK, Yard BA, Zuckermann A, Wagner F, et al. Impact of donor core body temperature on graft survival after heart transplantation. Transplantation. 2018;102:1891-900. https://doi. org/10.1097/TP.0000000000002337.

114. Huang FY, Huang BT, Wang PJ, Zuo ZL, Heng Y, Xia TL, et al. The efficacy and safety of prehospital therapeutic hypothermia in patients with out-of-hospital cardiac arrest: a systematic review and meta-analysis. Resuscitation. 2015;96:170-9. https://doi.org/10.1016/j.resuscitat ion.2015.08.005.

115. Axelrod DA, Malinoski D, Patel MS, Broglio K, Lewis R, Groat T, et al. Modeling the economic benefit of targeted mild hypothermia in deceased donor kidney transplantation. Clin Transplant. 2019;33:e13626. https:// doi.org/10.1111/ctr.13626.

116. de la Cruz JS, Sally MB, Zatarain JR, Crutchfield M, Ramsey K, Nielsen J, et al. The impact of blood transfusions in deceased organ donors on the outcomes of 1884 renal grafts from United Network for Organ Sharing Region 5. J Trauma Acute Care Surg. 2015;79:S164-70. https://doi. org/10.1097/TA.0000000000000670.

117. van Erp AC, van Dullemen LFA, Ploeg RJ, Leuvenink HGD. Systematic review on the treatment of deceased organ donors. Transplant Rev (Orlando). 2018;32:194-206. https://doi.org/10.1016/j.trre.2018.06.001.

118. Rosendale JD, Chabalewski FL, McBride MA, Garrity ER, Rosengard BR, Delmonico FL, et al. Increased transplanted organs from the use of a standardized donor management protocol. Am J Transplant. 2002;2:761-8. https://doi.org/10.1034/j.1600-6143.2002.20810.x.

119. Salim A, Velmahos GC, Brown C, Belzberg H, Demetriades D. Aggressive organ donor management significantly increases the number of organs available for transplantation. J Trauma. 2005;58:991-4. https://doi. org/10.1097/01.ta.0000168708.78049.32.

120. Salim A, Martin M, Brown C, Rhee P, Demetriades D, Belzberg H. The effect of a protocol of aggressive donor management: implications for the national organ donor shortage. J Trauma. 2006;61:429-33. https:// doi.org/10.1097/01.ta.0000228968.63652.c1.

121. Malinoski DJ, Daly MC, Patel MS, Oley-Graybill C, Foster CE, Salim A. Achieving donor management goals before deceased donor procurement is associated with more organs transplanted per donor. J Trauma. 2011;71:990-5. https://doi.org/10.1097/ta.0b013e31822779e5. 
122. Malinoski DJ, Patel MS, Daly MC, Oley-Graybill C, Salim A, workgroup URD. The impact of meeting donor management goals on the number of organs transplanted per donor: results from the United Network for Organ Sharing Region 5 prospective donor management goals study. Crit Care Med. 2012;40:2773-80. https://doi.org/10.1097/ccm.0b013 e31825b252a.

123. Marshall GR, Mangus RS, Powelson JA, Fridell JA, Kubal CA, Tector AJ. Donor management parameters and organ yield: single center results. J Surg Res. 2014;191:208-13. https://doi.org/10.1016/j.jss.2014.02.054.

124. Patel MS, De La Cruz S, Sally MB, Groat T, Malinoski DJ. Active donor management during the hospital phase of care is associated with more organs transplanted per donor. J Am Coll Surg. 2017;225:525-31. https ://doi.org/10.1016/j.jamcollsurg.2017.06.014.

125. Malinoski DJ, Patel MS, Ahmed O, Daly MC, Mooney S, Graybill CO, et al. The impact of meeting donor management goals on the development of delayed graft function in kidney transplant recipients. Am J Transplant. 2013;13:993-1000. https://doi.org/10.1111/ajt.12090.

126. Westphal GA, Zaclikevis VR, Vieira KD, Cordeiro Rde B, Horner MB, Oliveira TP, et al. A managed protocol for treatment of deceased potential donors reduces the incidence of cardiac arrest before organ explant. Rev Bras Ter Intensiva. 2012;24:334-40. https://doi.org/10.1590/ s0103-507×2012000400007.

127. Haynes AB, Weiser TG, Berry WR, Lipsitz SR, Breizat AH, Dellinger EP, et al. A surgical safety checklist to reduce morbidity and mortality in a global population. N Engl J Med. 2009;360:491-9. https://doi.org/10.1056/ NEJMsa0810119.

128. Pronovost $P$, Needham D, Berenholtz S, Sinopoli D, Chu H, Cosgrove $S$, et al. An intervention to decrease catheter-related bloodstream infections in the ICU. N Engl J Med. 2006;355:2725-32. https://doi. org/10.1056/NEJMoa061115.

129. Weiss CH, Moazed F, McEvoy CA, Singer BD, Szleifer I, Amaral LA, et al. Prompting physicians to address a daily checklist and process of care and clinical outcomes: a single-site study. Am J Respir Crit Care Med. 2011;184:680-6. https://doi.org/10.1164/rccm.201101-0037OC.

130. Writing Group for the C-ICUI, the Brazilian Research in Intensive Care, Cavalcanti AB, Bozza FA, Machado FR, Salluh Jl, et al. Effect of a quality improvement intervention with daily round checklists, goal setting, and clinician prompting on mortality of critically ill patients: a randomized clinical trial. JAMA. 2016;315:1480-90. https://doi.org/10.1001/ jama.2016.3463.

131. Ball IM, Hornby L, Rochwerg B, Weiss MJ, Gillrie C, Chasse M, et al. Management of the neurologically deceased organ donor: a Canadian clinical practice guideline. CMAJ. 2020;192:E361-9. https://doi.org/10.1503/ cmaj.190631.

132. Meyfroidt G, Gunst J, Martin-Loeches I, Smith M, Robba C, Taccone FS, et al. Management of the brain-dead donor in the ICU: general and specific therapy to improve transplantable organ quality. Intensive Care Med. 2019;45:343-53. https://doi.org/10.1007/s00134-019-05551-y.

133. National Academies of Sciences, Engineering, and Medicine. Opportunities for organ donor intervention research: Saving lives by improving the quality and quantity of organs for transplantation. Washington: The National Academies Press; 2017.

134. Helms AK, Torbey MT, Hacein-Bey L, Chyba C, Varelas PN. Standardized protocols increase organ and tissue donation rates in the neurocritical care unit. Neurology. 2004;63:1955-7. https://doi.org/10.1212/01. wnl.0000144197.06562.24

135. Franklin GA, Santos AP, Smith JW, Galbraith S, Harbrecht BG, Garrison $\mathrm{RN}$. Optimization of donor management goals yields increased organ use. Am Surg. 2010;76:587-94.

136. Westphal GA, Robinson CC, Biasi A, Machado FR, Rosa RG, Teixeira C, et al. DONORS (Donation Network to Optimise Organ Recovery Study): Study protocol to evaluate the implementation of an evidence-based checklist for brain-dead potential organ donor management in intensive care units, a cluster randomised trial. BMJ Open. 2019;9:e028570. https://doi.org/10.1136/bmjopen-2018-028570.

\section{Publisher's Note}

Springer Nature remains neutral with regard to jurisdictional claims in published maps and institutional affiliations.

\section{Submit your manuscript to a SpringerOpen ${ }^{\circ}$ journal and benefit from:}

- Convenient online submission

- Rigorous peer review

- Open access: articles freely available online

- High visibility within the field

- Retaining the copyright to your article

Submit your next manuscript at $\boldsymbol{\nabla}$ springeropen.com 